\title{
An eXOB mutant of Rhizobium sp. is effective in indeterminate nodules of Hedysarum coronarium
}

\author{
F. Javier Ollero, ${ }^{1}$ M. Angeles Valverde, ${ }^{1}$ Luis Sánchez-Palazón, ${ }^{2}$ Eduardo \\ Villalobo, ${ }^{1}$ M. Rosario Espuny ${ }^{1}$ and Ramón A. Bellogín ${ }^{1}$
}

Author for correspondence: Ramón A. Bellogín. Tel: +34 5 4557116. Fax: + 3454615780.

1 Departamento de
Microbiología, Facultad de
Biología, Universidad de
Sevilla, Apdo. 1095, 41080-
Sevilla, Spain
2 Departamento de
Microbiología, Facultad de
Ciencias, Universidad de
Córdoba, 14004-Córdoba,
Spain

\begin{abstract}
A Rhizobium sp. (Hedysarum coronarium) calcofluor dark (Cal-) mutant, named Cal10, was obtained following Tn5mob-insertion mutagenesis. It is affected in the synthesis of exopolysaccharide and presents an altered lipopolysaccharide that is not recognized by a polyclonal antibody against the lipopolysaccharide of the parental strain. The residual exopolysaccharide obtained from the mutant lacks galactose and the high-molecular-mass acidic fraction. This mutant was complemented by plasmid pD56 that restores the production of exopolysaccharide, the alteration of lipopolysaccharide and the $\mathrm{Cal}^{+}$ phenotype. The data presented indicate that the gene in which the mutant is defective is homologous to the exOB gene of Rhizobium meliloti and fails to synthesize UDP-glucose 4'-epimerase. The Cal10 mutant was Fix ${ }^{+}$on $\boldsymbol{H}$. coronarium (sulla) although it develops an indeterminate type of nodule, indicating that exopolysaccharide is not essential for a successful nodulation in this symbiotic association.
\end{abstract}

Keywords: Rbizobium sp., nodulation, symbiosis, exopolysaccharide, exoB

\section{INTRODUCTION}

Rhizobium strains produce exopolysaccharide (EPS). Several authors have demonstrated that EPS production is necessary for successful nodulation on legumes that develop an indeterminate type of nodule (nodules with a meristematic zone) such as alfalfa, peas or clovers (Borthakur $e$ t al., 1986; Chakravorty et al., 1982; Leigh et al., 1985; Canter Cremers et al., 1990). However, EPS does not seem to be essential for nodulation on legumes with determinate nodules without a meristematic zone such as beans or soybeans (Diebold \& Noel, 1989; Ko \& Gayda, 1990). Hotter \& Scott (1991) demonstrated that $R$. loti EPS mutants induce $\mathrm{Fix}^{+}$nodules on the determinate nodulating host Lotus pedunculatus and $\mathrm{Fix}^{-}$on the indeterminate nodulating host Leucaena leucocephala.

Lipopolysaccharide (LPS) also seems to be implicated in symbiosis. LPS is necessary for infection thread development in R. leguminosarum biovar phaseoli (Noel et al., 1986; Cava et al., 1989). A non-nodulating mutant or a mutant that nodulates very slowly has been described in Bradyrbizobium japonicum strains with altered LPS (Puvanesarajah et al., 1987; Stacey et al., 1982). However, Clover et al. (1989) have described several LPS mutants of R. meliloti that are not defective in symbiosis.

The exoB mutants of $R$. meliloti and $R$. leguminosarum biovar viciae are pleiotropic. They are defective in the synthesis of both EPS and LPS and induce empty ineffective nodules (Leigh et al., 1985; Leigh \& Lee, 1988) or only some root hair deformation and rare abortive infection threads (Canter Cremers et al., 1990). However, several exoB mutants of Bradyrbizobium japonicum are altered in their EPS but not LPS and form effective nodules on soybeans (Parniske et al., 1993) where a determinate type of nodule develops.

The exoB gene encodes a UDP-glucose 4'-epimerase in $R$. leguminosarum, R. meliloti and B. japonicum (Canter Cremers et al., 1990; Buendía-Clavería et al., 1991; Parniske et al., 1993).

In this work we describe an exoB mutant of Rhizobium sp. that induces effective nodules on its host plant Hedysarum coronarium, indicating that EPS is not essential in all symbiotic interactions in indeterminate nodule-type legumes. 
Table 1. Bacterial strains and plasmids

\begin{tabular}{|c|c|c|}
\hline $\begin{array}{l}\text { Strain and } \\
\text { plasmid }\end{array}$ & Characteristics* & Reference \\
\hline \multicolumn{3}{|l|}{ Strains } \\
\hline E. coli $\mathrm{S} 17-1$ & $\mathrm{Tp} \mathrm{p}^{\mathrm{r}}, \mathrm{Sm}^{\mathrm{r}}(\mathrm{pSUP5011})$ & Simon (1984) \\
\hline \multicolumn{3}{|l|}{$\begin{array}{l}\text { Rhizobium sp. } \\
(\text { H. coronarium })\end{array}$} \\
\hline IS123 & Wild type. & Espuny et al. (1987) \\
\hline RB16 & Spontaneous $\mathrm{Sm}^{\mathrm{r}}$ derivative of IS123. & Espuny et al. (1987) \\
\hline RJ 84 & $\begin{array}{l}\text { RB16 harbouring the pSym plasmid } \\
\text { tagged with } \operatorname{Tn} 5 \text { mob. }\end{array}$ & Ollero et al. (1989) \\
\hline RB19 & Spontaneous Rif derivative of IS123. & Ollero et al. (1989) \\
\hline Cal10 & $\begin{array}{l}\text { Tn } 5 \text { mob induced calcofluor dark } \\
\text { mutant of RB19. Kmr, Rifr. }\end{array}$ & This study \\
\hline \multicolumn{3}{|l|}{ Plasmids } \\
\hline pSUP5011 & $\operatorname{Tn} 5 m o b \mathrm{Ap}^{\mathrm{r}}, \mathrm{Cm}^{\mathrm{r}}$ & Simon (1984) \\
\hline pRK2013 & Helper. $\mathrm{Km}^{\mathrm{r}}$. & Ditta et al. (1980) \\
\hline pJB3JI & Helper. $T c^{r}, A p^{r}$. & Brewin et al. (1980) \\
\hline pD56 & $\begin{array}{l}\text { pLAFR1 cosmid from a } R \text {. meliloti } \\
\text { gene library complementing mutants } \\
\text { exoB, } Z, Q, F, Y, X\end{array}$ & Long et al. (1988) \\
\hline $\mathrm{pEX} 312$ & $\begin{array}{l}\text { pLAFR1 cosmid from a } R \text {. meliloti } \\
\text { gene library complementing mutants } \\
\text { exo } Z, Q, F, Y, X, H, K, L, A, M, N, P\end{array}$ & Long et al. (1988) \\
\hline pEX154 & $\begin{array}{l}\text { pLAFR1 cosmid from a } R \text {. meliloti } \\
\text { gene library complementing mutants } \\
\text { exoH, } K, L, A, M, N, P\end{array}$ & Leigh et al. (1987) \\
\hline
\end{tabular}

* Resistance to ampicillin $\left(A p^{r}\right)$, chloramphenicol $\left(\mathrm{Cm}^{r}\right)$, kanamycin $\left(\mathrm{Km}^{\mathrm{r}}\right)$, rifampicin $\left(\mathrm{Rif}^{\mathrm{r}}\right)$, streptomycin $\left(\mathrm{Sm}^{\mathrm{r}}\right)$, tetracycline $\left(\mathrm{Tc}^{\mathrm{r}}\right)$ and trimethoprim $\left(\mathrm{Tp}^{\mathrm{r}}\right)$.

\section{METHODS}

Strains, plasmids, media and bacterial matings. Bacterial strains and plasmids are listed in Table 1. Eschericbia coli strains were grown on LB medium and Rbizobium on TY (Beringer, 1974) or YM (Vincent, 1970) media. Antibiotics were added to media at the following concentrations $\left(\mu \mathrm{g} \mathrm{ml}^{-1}\right)$ : kanamycin (25) and tetracycline (10) for E. coli; and kanamycin (60), tetracycline (10), streptomycin (400), rifampicin (50) and nalidixic acid (20) for Rbizobium. Conditions for plasmid transfer by conjugation were performed as described by BuchananWollaston et al. (1980). In triparental matings the helper plasmids pRK2013 or pJB3JI were used.

Isolation of the Cal10 mutant. The parental strain RB19, which produces a calcofluor-binding EPS, was mutagenized with transposon Tn 5 mob by means of the suicide vector pSUP5011. The resulting bacterial clones were screened by plating on TY medium supplemented with rifampicin, kanamycin and $0.02 \%$ $(\mathrm{w} / \mathrm{v})$ calcofluor (Fluorescent Brightener 28, Sigma). A calcofluor dark colony was selected for further studies.

DNA isolation and manipulation. Plasmid profiles of rhizobia strains were visualized according to the agarose gel electrophoresis method of Eckhardt described previously (Espuny $e t$ al., 1987). Total Rhizobium DNA was isolated and purified by the method of Meade et al. (1982) and cut with EcoRI (Boehringer-Mannheim). A 870 bp Pst I fragment of the kanamycin resistance gene of $\operatorname{Tn} 5$ was used as a probe for hybridization, with digoxigenin labelling and Lumi-Phos detection (Boehringer-Mannheim).
Isolation and analysis of EPS. Bacteria were grown in YM broth for $7 \mathrm{~d}$ at $28^{\circ} \mathrm{C}$ in a rotary shaker. The EPS was isolated by precipitation from the culture supernatant with 2 vols acetone or 4 vols cold ethanol, or by the method of Diebold \& Noel (1989). The EPS was analysed by gel filtration chromatography, using a Sepharose $4 \mathrm{~B}$ column. The hexose content was measured by the anthrone method (Spiro, 1962). Uronic acid was assayed by reaction with $m$-hydroxydiphenyl (Blumenkrantz \& Asboe-Hanson, 1973). To determine the EPS composition, it was first hydrolysed in $1 \mathrm{M} \mathrm{HCl}$ acid for $5 \mathrm{~h}$ at $100{ }^{\circ} \mathrm{C}$ and then analysed by thin layer chromatography (TLC) using cellulose plates F-254 (Merck). The solvent used was butanol/pyridine/water (6:4:3, by vol.). The plates were developed with $5 \%$ triphenyltetrazolium chloride in methanol and $0 \cdot 25 \mathrm{M} \mathrm{NaOH}$.

Production of anti-LPS polyclonal antibodies. A rabbit was inoculated intramuscularly with $1.5 \mathrm{mg}$ LPS isolated according to Bellogín et al. (1984) and emulsified in $0.5 \mathrm{ml}$ Freund's complete adjuvant. Furthermore, subcutaneous inoculations with $1 \mathrm{mg}$ LPS emulsified in $0.5 \mathrm{ml}$ Freund's incomplete adjuvant were carried out according to the immunization scheme described in detail elsewhere (Sánchez-Palazón \& Rodríguez-Burgos, 1993). The antiserum obtained was assayed against LPS by the double diffusion technique.

Acrylamide gel electrophoresis for LPS analysis. Bacterial cells were harvested after growth to stationary phase in TY broth by centrifugation of $1 \mathrm{ml}$ samples. Pelleted cells were resuspended in $300 \mu \mathrm{l} \mathrm{Laemmli} \mathrm{solubilization} \mathrm{buffer} \mathrm{(Laemmli,} \mathrm{1970),} \mathrm{treated}$ with proteinase $\mathrm{K}\left(50 \mu \mathrm{g} \mathrm{ml}^{-1}\right)$ according to Sindhu et al. (1990) 
and subsequently separated using SDS-PAGE (15\% acrylamide). The LPS profile was visualized by a silver staining procedure described by Cava et al. (1989).

Immunoblotting. The gels were electroblotted for $1 \mathrm{~h}$ at $125 \mathrm{~mA}$ to nitrocellulose sheets in $48 \mathrm{mM}$ Tris, $39 \mathrm{mM}$ glycine, $20 \%(\mathrm{v} / \mathrm{v})$ methanol and $0.0375 \%(\mathrm{w} / \mathrm{v})$ SDS using a semi-dry LKB Multiphor II apparatus. Then the sheets were immunostained with the polyclonal antibody (dilution $1: 25$ ) using a peroxidase-conjugated $\operatorname{IgG}$ as the secondary antibody and developed using the Amersham ECL system, according to the manufacturer's instructions.

Enzyme assay for UDP-glucose 4'-epimerase. Bacteria were grown in YM medium, collected by centrifugation, and disrupted by sonication. Cell-free extracts were obtained by centrifugation at $26000 \mathrm{~g}$ for $1 \mathrm{~h}$ at $0^{\circ} \mathrm{C}$. UDP-glucose $4^{\prime}-$ epimerase was determined by the one-step method as described by Fukasawa et al. (1980). Protein concentration of crude extracts was determined by the Lowry method.

Plant tests. Seeds of Hedysarum coronarium ecotype Menorca, were sterilized and germinated, and plants were grown and inoculated as described previously (Espuny et al., 1987).

Light microscopy. Nodules 4 weeks old were removed, treated by the method of Hotter \& Scott (1991) and embedded in a Spurr's resin. For microscopy observations, $0.5 \mu \mathrm{m}$ sections were stained with toluidine blue (Hotter \& Scott, 1991).

\section{RESULTS}

\section{Isolation of calcofluor dark strains}

A calcofluor dark colony (named Cal10) was obtained after Tn 5 mob mutagenesis. Wild-type Rhizobium sp. RB19 colonies on YM medium were highly mucoid in appearance but the exo mutant Cal10 produced colonies that were non-mucoid on YM, and did not produce acetoneprecipitable EPS.

Rbizobium sp. RB19 harbours three plasmids with molecular masses of about 160, 230 and > $600 \mathrm{MDa}$ (Ollero et al., 1989). To see if the transposon Tn 5 mob was inserted within these plasmids, a blotted Eckhardt gel was hybridized using a $\operatorname{Tn} 5$ probe. A positive hybridization signal was detected from R J84, which harbours Tn 5 mob in the symbiotic plasmid, but was not detected from plasmid DNAs from the Cal10 mutant. Positive signals were detected around the agarose gel wells where large chromosomal DNA fragments were retained (data not shown).

Southern hybridization of total DNA digested by EcoRI revealed that the Cal10 mutant harbours one copy of the transposon located in an EcoRI fragment of $13.4 \mathrm{~kb}$ (data not shown). As the transposon Tn 5 mob is about $7.6 \mathrm{~kb}$ in size and EcoRI does not cut the transposon, the insertion is located in a Cal10 chromosomal DNA fragment of about $5.8 \mathrm{~kb}$.

\section{Analysis of EPS}

The Cal10 mutant did not produce acetone-precipitable EPS; however, it was possible to isolate some EPS using the Diebold \& Noel (1989) extraction method. It was estimated that parental strain RB19 produces about $0.0013 \mathrm{pg}$ per viable cell and the Cal10 mutant about $0 \cdot 00015 \mathrm{pg}$ per viable cell.
EPS from the parental strain was separated into two peaks by Sepharose 4B gel filtration, a high-molecular-mass acidic EPS fraction and a low-molecular-mass neutral EPS fraction (Fig. 1a). In contrast, the EPS of the Cal10 mutant resulted in one peak of low-molecular-mass neutral EPS (Fig. 1b).

In the hydrolysed EPS of parental strain RB19, spots indicating the presence of glucose and galactose were detected on TLC plates. The EPS of the Cal10 mutant lacks the galactose.

\section{Complementation of the Cal10 mutant by $R$. meliloti exo genes}

Several cosmid clones containing exo genes of R. meliloti have been described (Leigh et al., 1987; Long et al., 1988). In this work cosmids pD56, pEX154 and pEX312, which together harbour all described exo genes of $\mathrm{R}$. meliloti were used for complementation studies of the Cal10 mutant.

Only plasmid pD56, which harbours exoX, exoY, exoF, exoQ, exoZ and $e \times 0 B$ was able to complement the Cal10 mutant. The complemented mutant was $\mathrm{Cal}^{+}$, mucoid in YM medium and produced high-molecular-mass acidic

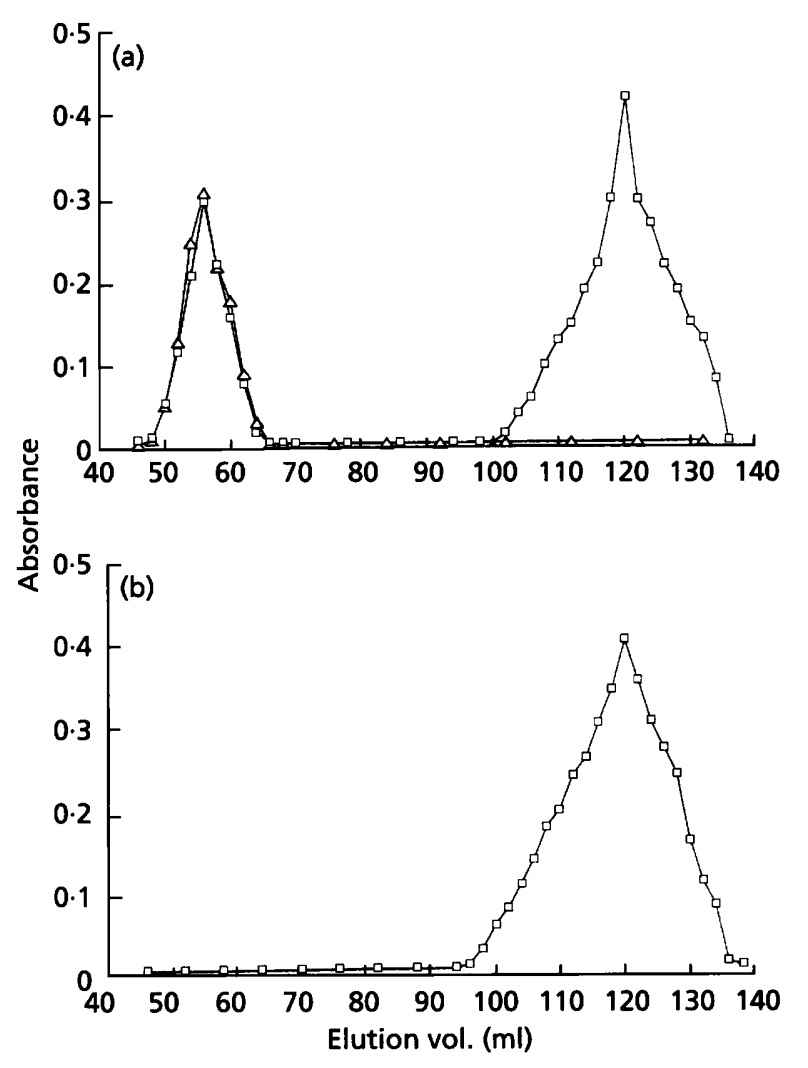

Fig. 1. Elution profile of a Sepharose $4 B$ gel filtration column of EPS from parental strain RB19 (a) and the Cal10 mutant (b). Hexose $(\square)$ was measured by the anthrone method $\left(A_{620}\right)$, and uronic acid $(\triangle)$ was assayed by reaction with $m$-hydroxydiphenyl $\left(A_{520}\right)$. In (a) the uronic acid peak is coincident with the first hexose peak. In (b) uronic acid was not detected. 
(a)

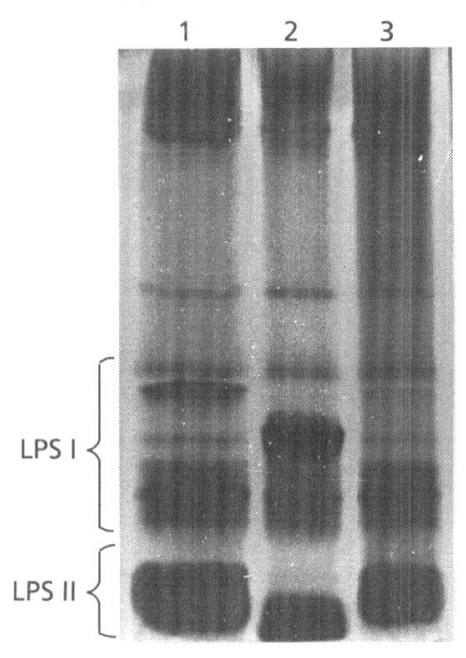

(b)

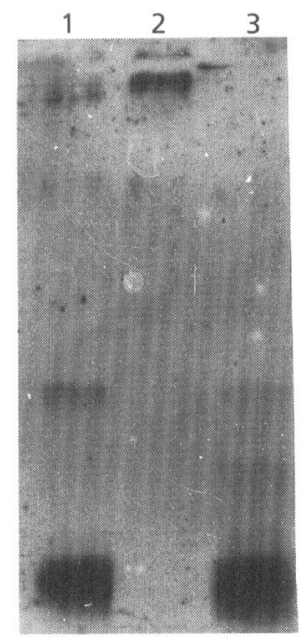

Fig. 2. (a) LPS profiles of Rhizobium sp. (H. coronarium) strain visualized by periodate oxidation and silver staining after electrophoresis on $15 \%$ acrylamide $(w / v)$ gels containing SDS. Lanes: 1, RB19; 2, Cal10; 3, Cal10(pD56). (b) Immunoblot, incubated with antiserum against RB19 LPS, of a duplicate gel corresponding to the one shown in (a).

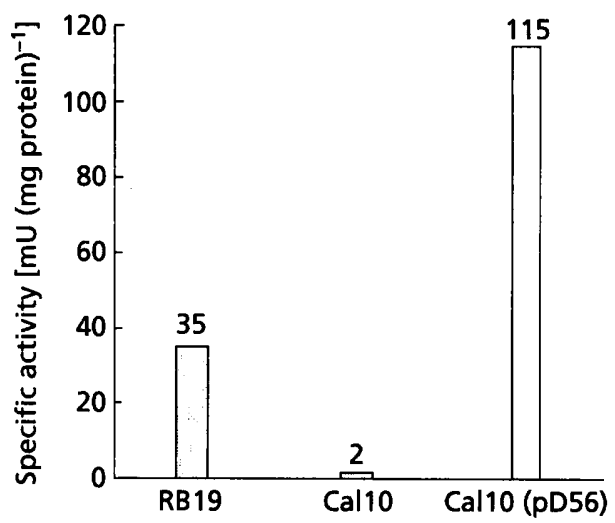

Fig. 3. UDP-glucose 4 '-epimerase activity of Rhizobium sp. ( $H$. coronarium) strains RB19, Cal10 and Cal10(pD56).

EPS. Plasmid pEX312 harbours all these exo genes except exoB, but does not complement Cal10, indicating that Cal10 is mutated in the $e x \circ B$ gene.

\section{Characterization of the Cal10 mutant}

The $e \times \circ B$ mutants have been described as pleiotropic and are affected in synthesis of both EPS and LPS (Canter Cremers et al., 1990). The LPS pattern of parental Rbizobium sp. strain RB19 consists of two parts, LPSI and LPSII (Fig. 2a). According to other authors (Sindhu et al., 1990), LPSI is presumably the entire LPS (lipid A, core and O-antigen) and LPSII, that migrated just behind the solvent front, consists of only lipid $A$ and core. Mutant Cal10 produced a LPS, which also consists of two parts, but both migrated faster than LPSI and LPSII of

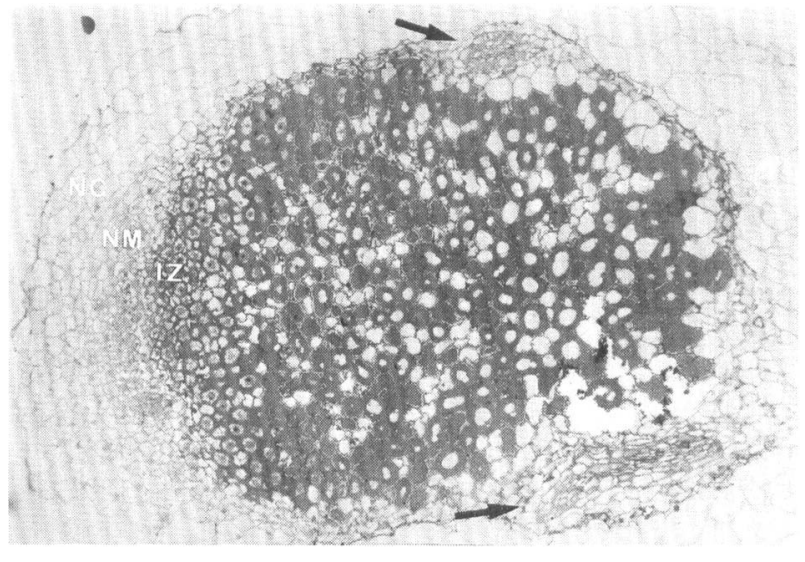

Fig. 4. Light microscopy photograph of a longitudinal section of a nitrogen-fixing nodule induced by the parental strain RB19. Nodule meristem (NM), nodule cortex (NC), invasion zone (IZ), nodular vascular bundles (arrows). Bar, $100 \mu \mathrm{m}$. Nodules induced by the Cal10 mutant exhibited the same structure.

the wild-type strain (Fig. 2a). The complemented Cal10(pD56) strain had the same LPS profile as the parental RB19 strain (Fig. 2a).

SDS-PAGE blots of LPS were incubated with antiserum against the parental strain LPS. The Cal10 mutant LPS was not recognized by this antiserum, while the LPS of the complemented Cal10(pD56) strain, like the parental strain LPS, was recognized (Fig. 2b).

The Cal10 exo::Tn 5 mob mutation was transferred by conjugation to strain RB16 ( $\mathrm{Sm}^{\mathbf{r}}$ derivative of wild-type Rbizobium sp. IS123). All $\mathrm{Km}^{\mathrm{r}}$ transconjugants were nonmucoid, $\mathrm{Cal}^{-}$, and had the same LPS profile as Cal10. Therefore, the exo mutation was at least closely linked to the $\operatorname{Tn} 5 m o b$ insertion.

To confirm that the Cal10 mutant fails to synthesize active UDP-glucose 4 '-epimerase, an enzymic assay for this enzyme was carried out using cell-free extracts prepared from Rbizobium sp. strains RB19, Cal10 and Cal10(pD56). The results showed that the Cal10 mutant lacks this enzymic activity (Fig. 3), while pD56 restores activity at an enhanced level that possibly reflects a higher copy number of the $e x o B$ gene.

Cal10, like the parental strain, grows on galactose as the sole carbon source.

\section{Symbiotic properties of the exoB mutant}

Rhizobium sp. strain IS123 induces cylindrical or branched nodules on $H$. coronarium (sulla). Light microscopic examination of the nodules showed a clearly visible meristematic zone (Fig. 4), typical of an indeterminate type of nodule.

The exoB mutant induced, on sulla, nodules that were comparable in number and morphology to those induced by wild-type strain RB19. Furthermore, mutants had the same nodulation kinetic and fixed nitrogen at the same 
rate as the wild-type strain. Bacteria recovered from nodules induced by mutants were phenotypically the same with regard to EPS production, LPS profile and antibiotic resistance as the original mutant Cal10.

\section{DISCUSSION}

In this paper we describe an exoB mutant of Rhizobium sp. $(H$. coronarium) which has been genetically and enzymically characterized. Like other exoB Rbizobium mutants, Cal10 is deficient in the synthesis of UDP-glucose $4^{\prime}$-epimerase.

This mutant is pleiotropic and both fails to synthesize EPS and presents an altered LPS, as do the exoB mutants described in R. meliloti and R. leguminosarum biovar viciae (Leigh \& Lee, 1988; Canter Cremers et al., 1990). The mutant is not mucoid and the residual EPS, isolated using the method described by Dielbold \& Noel (1989), lacks galactose residues and the acidic component (Fig. 1). These results suggest that the residual EPS isolated from the Cal10 mutant is a neutral $\beta$-glucan and the galactose must be a component of the acidic EPS fraction.

As can be seen in Fig. 2, the Cal10 mutant presents a LPS profile similar to the wild type but both LPSI and LPSII migrate faster than those corresponding to the parental strain. The Cal10 LPS is clearly an altered form of the wild-type LPS because it is not recognized by the antiwild-type LPS antibody.

In this paper we show that Cal10 lacks UDP-glucose $4^{\prime}$ epimerase, the enzyme that interconverts UDP-glucose and LDP-galactose. This explains the lack of galactose residues in the Cal10 EPS. Probably, the alteration in the Cal10 LPS could be a consequence of the lack of galactose residues. This would affect the polymerization degree of the LPS and for this reason the bands corresponding to LPSI and LPSII migrate faster than those corresponding to the wild-type strain. The absence of galactose residues in Cal10 LPS could also explain the incapacity of the antibody to recognize this LPS, indicating that galactose could be part of the epitope.

Like other Rhizobium exoB mutants, Cal10 is able to grow on galactose as sole carbon source, in contrast to E. coli galE mutants, where galactose as the unique carbon source is lethal (Adhya, 1987). Thus, Rbizobium sp. ( $H$. coronarium) also makes use of the De Ley-Doudoroff pathway for the conversion of galactose as do $R$. leguminosarum biovar trifolii (Ronson \& Primrose, 1979) and R. meliloti (Arias \& Cervenansky, 1986).

It has been reported that the exoB gene is necessary for successful nodulation on legumes that develop an indeterminate type of nodule (Leigh et al., 1985; Leigh \& Lee, 1988; Canter Cremers et al., 1990), but does not seem to be essential for nodulation on legumes with a determinate type of nodule (Parniske et al., 1993). However, we report in this paper an exoB mutant of Rbizobium sp. $(H$. coronarium $)$ that induces effective nodules on sulla, a legume that develops an indeterminate type of nodule (Fig. 4).

Williams et al. (1990) reported that the symbiotic defect
(Fix ${ }^{-}$) of R. meliloti exo mutants can be suppressed by the lps $Z^{+}$gene, which is present in $\mathrm{Rm} 41$ but not in SU47. Therefore the exoB mutants of $\mathrm{Rm} 41$ are $\mathrm{Fix}^{+}$. It is possible to suppose that the Rbizobium sp. strain RB19 harbours a $l p s Z^{+}$-like gene, and this could explain the $\mathrm{Fix}^{+}$ phenotype of our exoB mutant. Further work will be carried out to explore this possibility.

\section{ACKNOWLEDGEMENTS}

We wish to thank Dr T. Lynne Reuber for kindly providing plasmids pD56, pEX312 and pEX154. This work was supported by CICYT grant BIO 90-0987.

\section{REFERENCES}

Adhya, S. (1987). The galactose operon. In Eschericbia coli and Salmonella typhimurium: Cellular and Molecular Biology, pp. 1503-1512. Edited by F. C. Neidhardt, J. L. Ingraham, K. B. Low, B. Magasanik, M. Schaechter \& H. E. Umbarger. Washington, DC: American Society for Microbiology.

Arias, A. \& Cervenansky, C. (1986). Galactose metabolism in Rhizobium meliloti L5-30. J Bacteriol 167, 1092-1094.

Bellogín, R. A., Espuny, M. R., Gutierrez-Navarro, A. M. \& PérezSilva, J. (1984). Polysaccharide and lipopolysaccharide and infectivity of Rhizobium trifolii. Soil Biol Biochem 16, 23-26.

Beringer, J. E. (1974). R factor transfer in Rbizobium leguminosarum. $J$ Bacteriol 84, 188-198.

Blumenkrantz, N. \& Asboe-Hanson, G. (1973). New method for quantitative determination of uronic acids. Anal Biocbem 54, 484-489.

Borthakur, D., Barker, R. F., Lamb, J. W., Daniels, M. J., Downie, J. A. \& Johnston, A.W. B. (1986). A mutation that blocks exopolysaccharide synthesis prevents nodulation of peas by $\mathrm{R} h i$ zobium leguminosarum but not of beans by $R$. phaseoli and is corrected by cloned DNA from Rhizobium or the phytopathogen Xantbomonas. Mol \& Gen Genet 203, 320-323.

Brewin, N. J., Beringer, J. E. \& Johnston, A. W. B. (1980). Plasmid mediated transfer of host-range between two strains of Rbizobium leguminosarum. J Gen Microbiol 120, 413-420.

Buchanan-Wollaston, A. V., Beringer, J. E., Brewin, N. J., Hirsch, P. R. \& Johnston, A. W. B. (1980). Isolation of symbiotically defective mutants in Rbizobium leguminosarum by insertion of the transposon Tn 5 into a transmissible plasmid. Mol \& Gen Genet 178, 185-190.

Buendía-Clavería, A., Enenkel, B., Köplin, R., Niehaus, K., Arnold, W. \& Pühler, A. (1991). The Rhizobium meliloti exoZ/exoB fragment of megaplasmid 2: ExoB functions as a UDP-glucose 4-epimerase and ExoZ shows homology to NodX of Rhizobium leguminosarum biovar viciae strain TOM. Mol Microbiol 5, 1519-1530.

Canter Cremers, H. C. J., Batley, M., Redmond, J. W., Eydems, L., Breedveld, M., Zevenhuizen, L. P. T. M., Pees, E., Wijffelman, C. A. \& Lugtenberg, B. J. J. (1990). Rbizobium leguminosarum exoB mutants are deficient in the synthesis of UDP-glucose $4^{\prime}$-epimerase. $J$ Biol Chem 265, 21122-21127.

Cava, J. R., Elias, P. M., Turowski, D. A. \& Noel, K. D. (1989). Rbizobium leguminosarum CFN42 genetic regions encoding lipopolysaccharide structures essential for complete nodule development on bean plants. $J$ Bacteriol 171, 8-15.

Chakravorty, A. K., Zurkowski, W., Shine, J. \& Rolfe, B. G. (1982). Symbiotic nitrogen fixation: molecular cloning of Rhizobium genes involved in exopolysaccharide synthesis and effective nodulation. $J$ Mol Appl Genet 1, 585-596. 
Clover, R. H., Kieber, J. \& Signer, E. R. (1989). Lipopolysaccharide mutants of Rbizobium meliloti are not defective in symbiosis. $I$ Bacteriol 171, 3961-3967.

Diebold, R. \& Noel, K. D. (1989). Rhizobium leguminosarum exopolysaccharide mutants: biochemical and genetic analysis and symbiotic behaviour on three hosts. J Bacteriol 171, 4821-4823.

Ditta, G., Standfield, S., Corbin, D. \& Helinski, D. R. (1980). Broad host range DNA cloning system for Gram-negative bacteria: construction of a gene bank of Rhizobium meliloti. Proc Natl Acad Sci US A 77, 7347-7351.

Espuny, M. R., Ollero, F. J., Bellogín, R. A., Ruíz-Sainz, J. E. \& Pérez-Silva, J. (1987). Transfer of the Rbizobium leguminosarum biovar trifolii plasmid pRtr5a to a strain of Rbizobium sp. that nodulates Hedysarum coronarium. J Appl Microbiol 63, 13-20.

Fukasawa, T., Obonai, K., Segawa, T. \& Nogi, Y. (1980). The enzymes of galactose cluster in Saccharomyces cerevisiae. J Biol Chem 255, 2705-2707.

Hotter, G. S. \& Scott, B. D. (1991). Exopolysaccharide mutants of Rhizobium loti are fully effective on a determinate nodulating host but are ineffective on an indeterminate nodulating host. $J$ Bacteriol 173, 851-859.

Ko, Y. H. \& Gayda, R. (1990). Nodule formation in soybeans by exopolysaccharide mutants of Rhizobium fredii USDA 191. J Gen Microbiol 136, 105-113.

Laemmli, U. K. (1970). Cleavage of structural proteins during the assembly of the head of bacteriophage T4. Nature 227, 680-685.

Leigh, J. A. \& Lee, C. C. (1988). Characterization of polysaccharide of Rhizobium meliloti exo mutants that form ineffective nodules. $J$ Bacteriol 170, 3327-3332.

Leigh, J. A., Signer, E. R. \& Walker, G. C. (1985). Exopolysaccharide deficient mutants of Rbizobium meliloti that form ineffective nodules. Proc Natl Acad Sci USA 82, 6231-6235.

Leigh, J. A., Reed, J. W., Hanks, J. F., Hirsch, A. M. \& Walker, G. C. (1987). Rbizobium meliloti mutants that fail to succinylate their calcofluor-binding exopolysaccharide are defective in nodule invasion. Cell 51, 579-587.

Long, S., Reed, J. W., Himawan, J. \& Walker, G. C. (1988). Genetic analysis of a cluster of genes required for synthesis of the calcofluorbinding exopolysaccharide of Rhizobium meliloti. J Bacteriol 170, 4239-4248.

Meade, H. M., Long, S. R., Ruvkun, G. B., Brown, S. E. \& Ausubel, F. M. (1982). Physical and genetic characterization of symbiotic and auxotrophic mutants of Rbizobium meliloti induced by transposon Tn5 mutagenesis. J Bacteriol 149, 114-122.

Noel, K. D., Vandenbosch, K. A. \& Kulpaca, B. (1986). Mutations in Rhizobium phaseoli that lead to arrested development of infection threads. J Bacteriol 168, 1392-1401.

Ollero, F. J., Espuny, M. R. \& Bellogín, R. A. (1989). Mobilization of a symbiotic plasmid of a strain of Rhizobium sp. (Hedysarum coronarium). Syst Appl Microbiol 11, 217-222.

Parniske, M., Kosch, K., Werner, D. \& Müller, P. (1993). ExoB mutants of Bradyrbizobium japonicum with reduced competitiveness for nodulation of Glycine max. Mol Plant-Microbe Interact 6, 99-106.

Puvanesarajah, V., Schell, F. M., Gerhold, D. \& Stacey, G. (1987). Cell surface polysaccharide from Bradyrbizobium japonicum and a non-nodulating mutant. $J$ Bacteriol 169, 137-141.

Ronson, C. W. \& Primrose, S. B. (1979). Carbohydrate metabolism in Rbizobium trifolii: identification and symbiotic properties of mutants. J Gen Microbiol 112, 77-88.

Sánchez-Palazón, L. \& Rodríguez-Burgos, A. (1993). Protein synthesis by chick (Gallus domesticus) extraembryonic membranes. Comp Biochem Physiol 104B, 689-693.

Simon, R. (1984). High frequency mobilization of Gram-negative bacteria replicons by in vitro constructed $\mathrm{Tn} 5$ mob transposon. Mol \& Gen Genet 196, 413-420.

Sindhu, S. S., Brewin, N. J. \& Kannenberg, E. L. (1990). Immunochemical analysis of lipopolysaccharide from free-living and endosymbiotic forms of Rbizobium leguminosarum. J Bacteriol 172, 1804-1813.

Spiro, R. G. (1962). Analysis of sugar found in glycoproteins. Methods Enzymol 8, 3-26.

Stacey, G., Paau, A. S., Noel, K. D., Maier, E. J., Silver, R. J. \& Brill, W. J. (1982). Mutants of Rbizobium japonicum defective in nodulation. Arch Microbiol 132, 219-224.

Vincent, J. M. (1970). A Manual for the Practical Study of Root Nodule Bacteria. Oxford: Blackwell Scientific Publications.

Williams, M. N. V., Hollingsworth, R. I., Klein, S. \& Signer, E. R. (1990). The symbiotic defect of Rbizobium meliloti exopolysaccharide mutants is suppressed by $l p s Z^{+}$, a gene involved in lipopolysaccharide biosynthesis. J Bacteriol 172, 2622-2632.

Received 3 August 1993; revised 2 December 1993; accepted 31 December 1993. 